\title{
Liver histological, portal flow and plasmatic nitric oxide alterations caused by biliary obstruction and drainage in rats ${ }^{1}$
}

\author{
Alterações histológicas, do fluxo portal e do óxido nítrico plasmático em ratos submetidos à obstrução/ \\ desobstrução biliar ${ }^{1}$
}

\author{
Miguel Angel Dias ${ }^{\mathrm{I}}$, Reginaldo Ceneviva ${ }^{\mathrm{II}}$, Jorge Elias Jr."I, Sergio Zucoloto ${ }^{\mathrm{IV}}$, Caroline Floreoto Baldo ${ }^{\mathrm{V}}$, Paulo Roberto \\ Barbosa Évora ${ }^{\mathrm{VI}}$

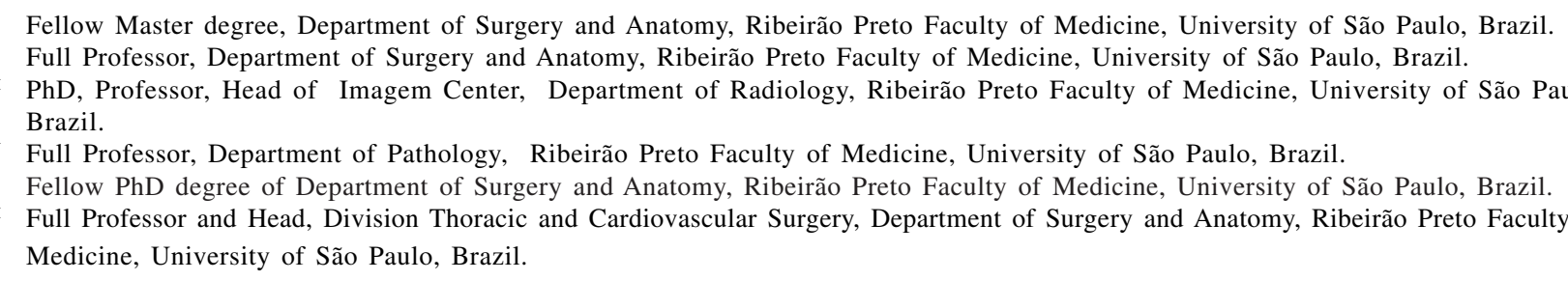

\begin{abstract}
Purpose: To evaluate liver alterations caused by biliary obstruction and drainage. Methods: Thirty-nine male Wistar rats were randomly distributed in 4 groups: BO $(n=18)$ bile duct ligation for 20 days, with a periodic evaluation of liver histological alterations, Doppler echography portal flow and measurements of NO and malondialdehyde (MDA); BO/DB $(\mathrm{n}=13)$ bile duct occlusion for 20 days followed by biliary drainage by choledochoduodenal anastomosis, 5 days followup, same BO group parameters evaluations; group CED $(n=4)$ sham operation and portal flow evaluation trough 20 days; CHB $(n=4)$ sham operation, with hepatic biopsy on $25^{\text {th }}$ day and followed-up trough 25 days, by the same parameters of group BO, with exception of portal flow. Direct bilirubin (DB) and alkaline phosphatase (AP) were evaluated in the group BO, BO/DB and CHB. Results: The bile duct ligation led to an increase of DB and AP, development of liver histological alterations, reduction of portal flow and increase of plasmatic NO and of MDA levels. The bile duct clearing resulted in a reduction of DB, AP, NO, MDA histological alterations and increase of portal flow. Conclusion: The biliary occlusion resulted in cholestasis and portal flow reduction, besides the increase of plasmatic NO and of hepatic MDA levels, and histological liver alterations, with a tendency of normalization after the bile duct clearing.
\end{abstract}

Key words: Liver. Portal Flow. Nitric Oxide. Biliary Obstruction. Cholestasis. Lipid Peroxidation. Malondialdehyde

\section{RESUMO}

Objetivo: Avaliar alterações hepáticas resultantes do processo de obstrução/desobstrução biliar. Métodos: Trinta e nove ratos Wistar foram distribuídos aleatoriamente em 4 grupos: OB (n=18), oclusão biliar, seguimento de 20 dias, avaliação das alterações histológicas hepáticas, do fluxo portal e dosagens de NO e de malondialdeído (MDA); grupo OB/DB (n=13) oclusão biliar por 20 dias seguida de desobstrução biliar por anastomose colédoco-duodenal, seguimento por 5 dias e avaliação dos mesmos parâmetros do grupo BO; grupo CED (n=4) operação simulada, avaliação do fluxo portal e seguimento por 25 dias; grupo CHB $(n=4)$ operação simulada com biópsia hepática no $25^{\circ}$ dia, e seguido por 25 dias com avaliação periódica dos mesmos parâmetros do grupo BO, com exceção da ecografia Doppler. Nos grupos BO, OB/DB e CHB foram avaliadas também a bilirrubina direta (BD) e a fosfatase alcalina (FA). Resultados: A oclusão do colédoco causou aumento da BD e da FA, desenvolvimento de alterações hepáticas, redução do fluxo portal, com aumentos do NO plasmático e do MDA. A desobstrução biliar resultou na redução da BD, da FA, das alterações hepáticas, aumento do fluxo portal e redução do NO e do MDA. Conclusão: A obstrução biliar resultou em colestase, alterações histológicas hepáticas, diminuição do fluxo portal, aumentos do NO plasmático e MDA hepático, com tendência à normalização após a desobstrução biliar.

Descritores: Fígado. Fluxo Portal. Óxido Nítrico. Obstrução Biliar. Colestase. Peroxidação Lipídica. Malondialdeido.

1. Work performed at the Department of Surgery and Anatomy, Ribeirão Preto Faculty of Medicine, University of São Paulo, Brazil. 


\section{Introduction}

Benign extra-hepatic cholestasis may lead to cholangitis and increased intra-canaliculi pressure, developing acute and chronic hepatic injuries ${ }^{1,2}$ reduced portal flow, ${ }^{3-6}$ increased serum nitric oxide $(\mathrm{NO})^{7-9}$ and triggering of liver lipid peroxidation. ${ }^{10-12}$ Surgical desobstruction is the elective treatment.

Acute liver injuries results, among others, mainly in abscesses, ductal proliferation and reduced number of hepatocyte ${ }^{2}$ while secondary biliary cirrhosis is aroused due to chronic injuries. ${ }^{13}$ Portal flow may be reduced up to $50 \%$ in 7 days. ${ }^{6}$ Quantitative and qualitative alterations of the free radicals (FR) enzymes, constitutive NO isoforms $(\mathrm{cNOS})^{14,15}$ and the presence of inducible isoform (iNOS) following the outcome of inflammatory process ${ }^{9}$ promotes increases of NO concentration. The accumulation of hydrophobic bile acids during cholestasis leads to mitochondrial FR generation in the liver, consisting of a major mechanism of injury and fibrosis due to the propagation of the lipid peroxidation chain after spontaneous reaction with oxygen. ${ }^{11,16,17}$

Histological injuries reduced portal flow, increased plasma NO and liver lipid peroxidation associated with extrahepatic cholestasis are events reported by pertinent literature in a isolated manner.

The proposal of this study is to evaluate the above parameters simultaneously in the same experimental model. New investigations are worthwhile to better understand the relation between the aggravating factors of extra-hepatic cholestasis, especially NO and portal flow.

\section{Methods}

Twenty six male Wistar rats, weight range 230 e 370 $\mathrm{g}$, were randomly distributed into 3 groups. Group 1: Biliary Occlusion (BO), $n=18$, submitted to biliary occlusion after sectioning and ligature of choledoch duct. Doppler echography were performed on days 0,15 and 20 to evaluate portal flow and obtain liver biopsy, whereby 650 and 900 $\mathrm{mg}$ pieces were removed for histology and for dosage of NO and malondialdehyde (MDA). Simultaneously, blood was collected from the inferior cava vein for dosage of NO, direct bilirubin (DB) and alkaline phosphatase (AP). Hepatic tissue histology and morphometry were done with biopsy fragments obtained during sacrifice. Group 2: Simulated biliary obstruction as control of portal flow through Doppler echography, (CED), n=4, submitted to biliary simulated obstruction as control for Doppler echography, performed on days 0,15 and 20. Group 3: Simulated biliary obstruction as control for histology and biochemical dosages, (CHB), $\mathrm{n}=4$, submitted to simulated biliary obstruction and afterwards to hepatic biopsy for dosage of NO and MDA and blood withdrawal on days 0, 15 and 20.

Surgical procedure: After 12 hours of fasting and water ad libitum, the animals were anesthetized by ethyl ether inhalation. Group BO: xiphopubic median laparotomy, acknowledge and distal ligature of choledochus, biopsy pieces removed from the left lobe of the liver on day 0 , from the right lobe on day 15 and again left lobe on day 20 with posterior suture. Collection of $2.5 \mathrm{~mL}$ of blood from the inferior cava vein. Careful and meticulous hemostasis and abdominal closure in two planes. Groups CED and CHB were submitted to simulated surgery (Figure 1).

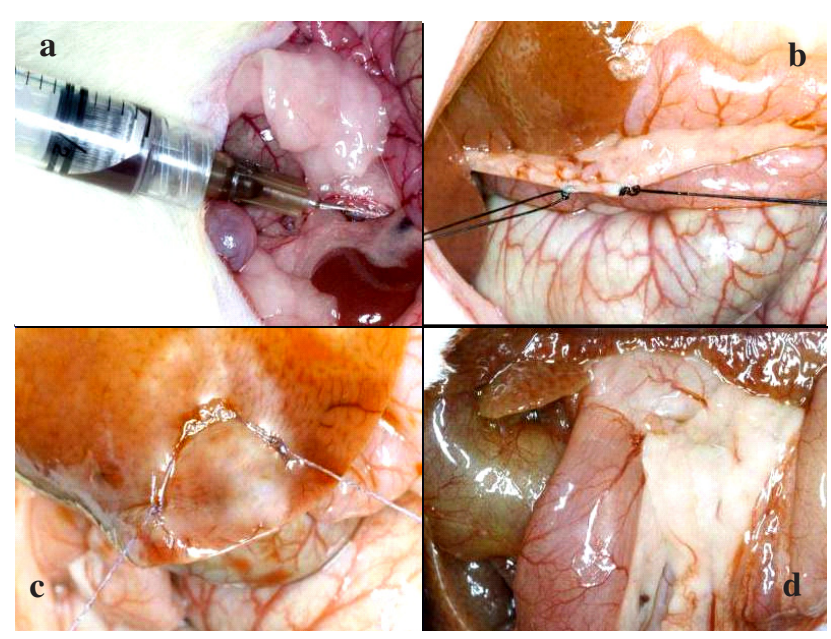

FIGURE 1 - a) Blood collection from inferior cava vein, b) Double ligature of choledochus, c) Delimitating suture of the hepatic area where biopsy is performed and d) Visualization of the dilated choledochus adjoining to the duodenum.

Histology: Hematoxylin-eosin stain was employed and hepatic tissue morphometry was performed by the evaluation of the volume fractions calculated from the fraction of points overlaying a specific compartment divided by the total number of points counted, which was calculated for hepatocytes, fibroblasts, fibrosis, biliary ducts, blood vessels and inflammatory cells contained in the hepatic tissue.

Direct Bilirubin (DB) and alkaline phosphatase $(A P)$ : were determined respectively, by the SIMS \& HORN (1958) and ROY (1970) colorimetric method.

Portal Flow: Coloured and spectral Doppler, portable equipment, model LOGIQ Book, GE Medical Systems, with multifrequencies ( 5 a $10 \mathrm{MHz}$ ) linear electronic transducer, EEUU.

Plasma Nitric Oxide (NO): Indirect determination trough dosage of nitrate by the Sievers NO Analizer, EEUU; tissular: indirect determination through dosage of nitrate by Griess solution.

Malondialdehyde (MDA): measurements performed by specific kit with methodology described by BUEGE and AUSSI (1978).

Statistical analysis: To compare statistical significance within groups analysis of variance (ANOVA) test was used. Between groups, two-way ANOVA was applied. Comparative analysis was made using Friedman test for each group and Kruskal-Wallis and Mann-Whitney for each day. The morphometric evaluation was analyzed using the $\mathrm{X}^{2}$-test for binomial proportions of some characteristics presented in the animals. 


\section{Results}

Histology: Microscopic evaluation of the hepatic tissue in group BO revealed reduced number of hepatocytes, as well as ductal proliferation, vascular neoformation, inflammatory cells, fibrosis and apoptotic corpuscles. On the other hand, control had no unexpected findings. Morphometric analysis performed by the $\mathrm{X}^{2}$-test shows significant difference to hepatocytes, fibroblasts, fibrosis, ducts and inflammatory cells (Figure 2).

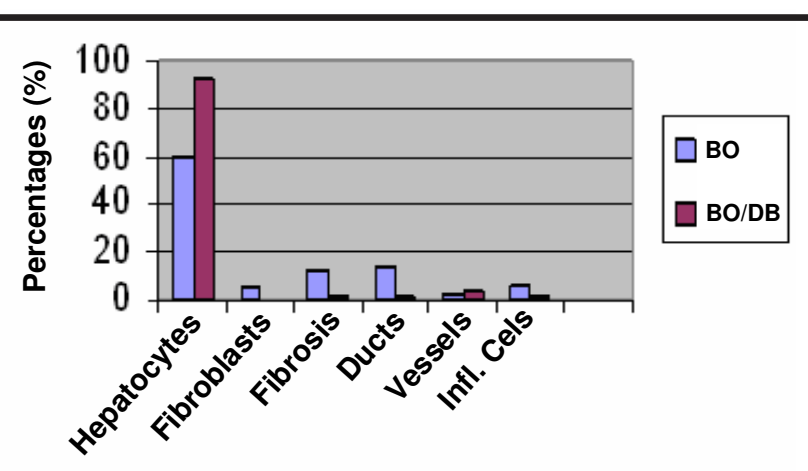

FIGURE 2 - Morphometric evaluation of hepatic tissue. Data is presented as mean. $\mathrm{p}<0,001$ for group BO (20 days) versus group BO/DB (25 days).

Direct bilirubin: Analysis within group demonstrated in group BO significant difference between basal value and days $15(\mathrm{p}=0,016)$ and $20(\mathrm{p}=0,02)$. Analysis between groups revealed significant difference of $\mathrm{DB}$ values on days 15 and 20 in groups $\mathrm{BO}$ and control $(\mathrm{p}=0,0002)$ and $(\mathrm{p}=0,0046)$ (Figure 3).

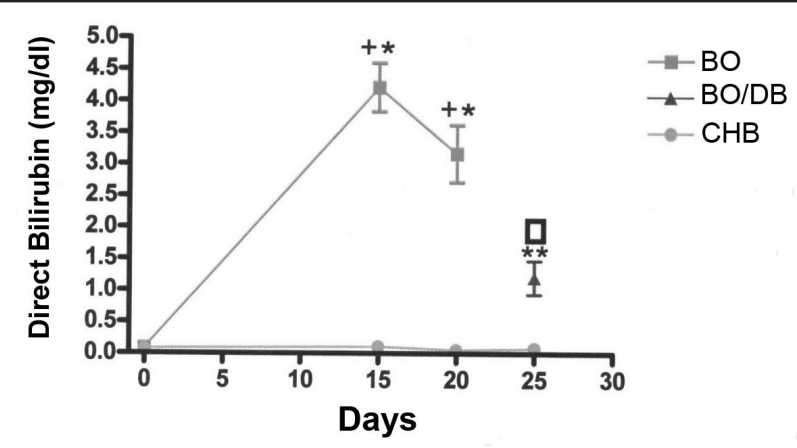

FIGURE3 - Direct bilirubin. Data are presented as means \pm SD. $+\mathrm{p}<0,05$ for basal (15 days) versus group BO (15 and 20 days); * $\mathrm{p}<$ 0,05 for group $\mathrm{BO}(15$ and 20 days $)$ versus group CHB (15 and 20 days); ** $\mathrm{p}<0,05$ for group BO/DB (25days) versus group CHB (25 days); $\square \mathrm{p}<0,05$ for group $\mathrm{BO} /$ DB (25 days) versus group BO (20 days).

Alkaline phosphatase: Analysis within group demonstrated in group BO significant difference between basal value and days $15(\mathrm{p}=0,064)$ and $20(\mathrm{p}=0,016)$. Analysis between groups revealed significant difference of AP values on days 15 and 20 in groups $\mathrm{BO}$ and control $(\mathrm{p}=0,003)$ and $(\mathrm{p}=0,002)$ (Figure 4).

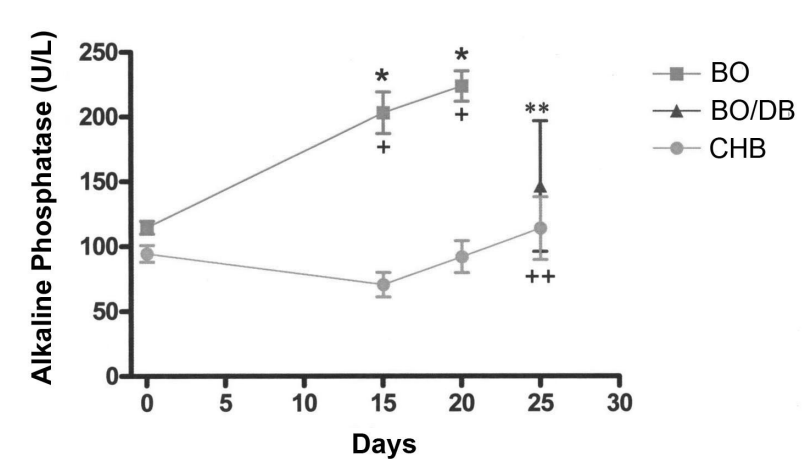

FIGURE4- $\quad$ Alkaline phosphatase. Data are presented as means \pm SD. + p $<0.05$ for basal value versus $\mathrm{BO}$ (15 and 20 days); $++\mathrm{p}<0.05$ for basal values versus group CHB (25 days) group; * $\mathrm{p}<0,05$ for group BO (15 and 20 days) versus group CHB (15 and 20 days); $* * \mathrm{p}<0,05$ for group BO/DB (25 days) versus group $\mathrm{CHB}$ (25 days).

Portal flow: In group BO mean portal flow value on day 15 was significantly higher than on day 0 , on the contrary, day 20 presented significantly reduced value than day 15. In group CED, greater statistically different values was observed for on day 20 compared to basal (Figure 5).

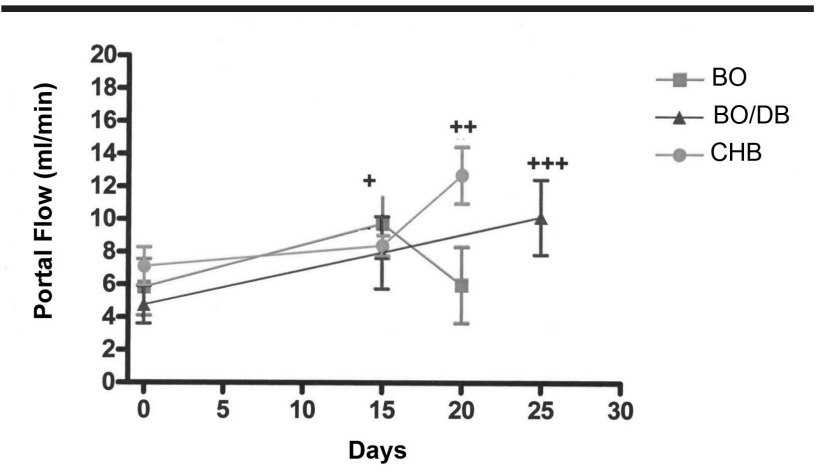

FIGURE5 - Portal flow. Data are presented as means $\pm \mathrm{SD} .+\mathrm{p}<0.05$ for basal values versus group BO (15 and 20 days); ++ $\mathrm{p}<0.05$ basal value versus group CED (20 days); $+++\mathrm{p}=0.05$ for basal value versus group BOD/DB (25 days).

Nitric Oxide: For NO plasma values statistical significance was observed within group BO on days 15 and 20 compared to basal value $(\mathrm{p}=0,032$ and 0,007 , respectively). Similar results were noticed between groups BO and control ( $\mathrm{p}=0,028$ and 0,028 respectively) on days 15 and 20. Hepatic tissue did not reveal significant difference either within or between groups (Figure 6). 

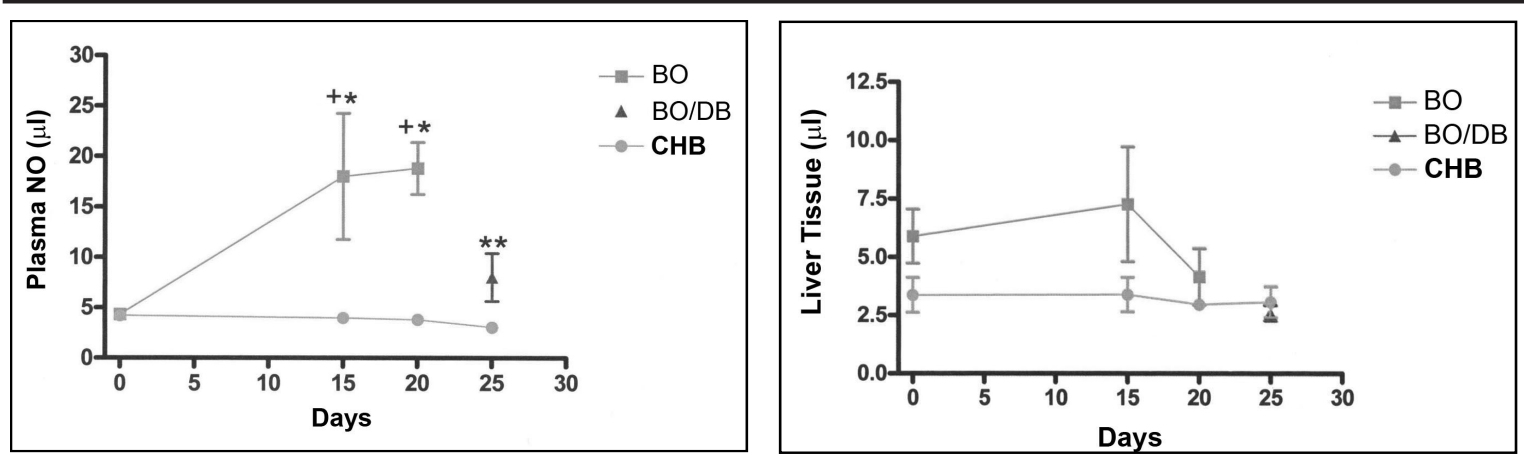

FIGURE 6 - Plasma NO. Data are presented as means \pm SD. $+\mathrm{p}<0,05$ basal value versus group BO (15 and 20 days); $*$ p $<0,05$ for group BO (15 and 20 days) versus group CHB (15 and 20 days); $* * \mathrm{p}<0,05$ for group $\mathrm{BO} / \mathrm{DB}(25$ days ) versus $\mathrm{t}=25$ days in group $\mathrm{CHB} ; \square \mathrm{p}<0,05$ for group $\mathrm{BO} / \mathrm{DB}$ (25 days) versus group BO (20 days). No differences in NO liver tissue.

Malondialdehyde: Statistical significance was observed between groups OB and CHB on days $15(\mathrm{p}=0,048)$ and $20(\mathrm{p}=0,042)$ (Figure 7$)$.

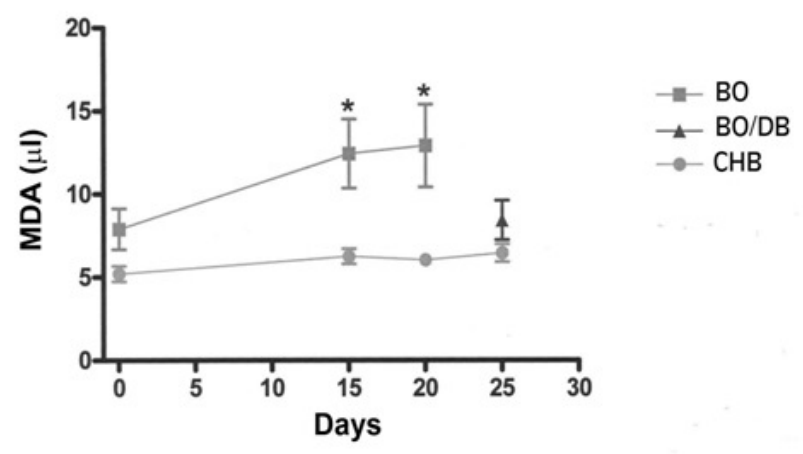

FIGURE 7 - Liver tissue malondialdehyde. Data are presented as means \pm SD. $+\mathrm{p}<0,05$ for basal value versus group BO (15 and 20 days); $* \mathrm{p}<0,05$ for group $\mathrm{BO}(15$ and $2 \mathrm{O}$ days) versus group CHB (15 and 20days); $* * \mathrm{p}<0,05$ for group BO/DB (25 days) versus group CHB (25 days); $\square \mathrm{p}<0,05$ for group $\mathrm{BO} / \mathrm{DB}$ (25 days) versus group BO (20 days).

\section{Discussion}

Contrary to literature data which reports events related to extra-hepatic cholestasis in a isolated manner, the present experiment proposed a simultaneous study of hepatic histological alterations and DB, AP, portal flow, plasma and hepatic NO, and hepatic MDA by performing biliary obstruction in rats. Results demonstrated acute histological alterations, significant rises in DB and AP in the occluded group, significant reduction of portal vein flow, significant augment of plasma NO and hepatic MDA revealing hepatic lipid peroxidation. Reduced portal flow may be attributed to portal vein compression by intense biliary tree dilation, on account that on day 20 there was a significant reduction of portal flow not correspondent to the concomitant rise of plasma NO. Nevertheless, the significant increase in plasma NO may imply in portal vasodilation and consequent decline in flow. Negative findings related to NO in the hepatic tissue, may call to mind that the method using Griess solution chosen by this study, must be substituted by imunohistochemistry. ${ }^{18,19}$

In a simplified manner and based on pertinent literature, the following sequence of physiopathologic events may be suggested:

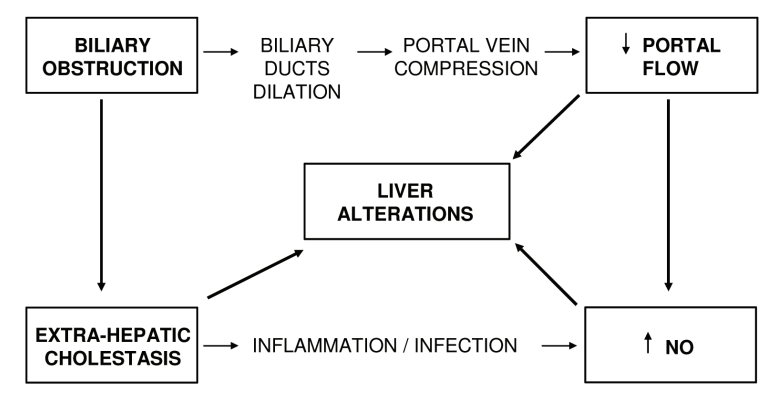

\section{Conclusion}

Biliary obstruction results in morphologic (histology) and functional (increases in direct bilirubin and alkaline phosphatase) alterations of the liver, concomitant to reduction in portal flow and increase of plasmatic NO and hepatic tissue MDA.

\section{References}

1. Oliveira e Silva A, Meniconi MTM, Copstein JLM, Santos Jr ED, Mancero JMP, Quireze Jr CQ, Paula Filho U, Carneiro D'Albuquerque LA. Colestase 
extra-hepática. In: Oliveira e Silva. A \& Carneiro D’Albuquerque LA. Doenças do Fígado, Editora Revinter. 2001;320-47.

2. Prado IB, Santos MHH, Lopasso FP, Iriya K, Laudanna AA. Cholestasis in a murine experimental model: Lesions include hepatocyte ischemic necrosis. Rev Hosp Clín Fac Med SP. 2003;58:27-32.

3. Biecker E, Sägesser H, Reichen J. Vasodilatador mRNA levels are increased in the livers of portal hipertensive NO-synthase 3-deficient mice. Eur J Clin Invest. 2004;34:283-8.

4. Castro e Silva Jr. O. Função mitocondrial no fígado durante a obstrução biliar extra-hepática e após drenagem cirúrgica das vias biliares. Efeito da clorpromazina. Tese de Doutorado Faculdade de Medicina de Ribeirão Preto Universidade de São Paulo, Ribeirão Preto, 1986.

5. Castro e Silva Jr. O. Fluxo portal e atividade enzimática da piruvato quinase na obstrução biliar extra-hepática. Tese Livre Docência. Faculdade de Medicina de Ribeirão Preto Universidade de São Paulo. Ribeirão Preto, 1991.

6. Roselino JES, Castro e Silva O, Ceneviva R. Lack of control of liver gluconeogenesis in cholestatic rats with reduced portal blood flow. Hepatology. 1992;16:1055-60.

7. Mayoral P, Criado M, Hidalgo F, Flores O, Arévalo MA, Eleno N, Sánchez-Rodriguez A, López-Novoa JM, Esteller A. Effects of chronic oxide activation or inhibition on early hepatic fibrosis in rats with bile duct ligation. Clin Sci. 1999;96:297-305.

8. Miranda LE. O papel da artéria hepática na lesão por isquemía e reperfusão do fígado canino: estudo in vitro do relaxamento arterial dependente do óxido nítrico. Tese Doutorado. Faculdade de Medicina de Ribeirão Preto, USP, 2002.

9. Rodrigo J, Alonso D, Fernández AP, Serrano J., López JC, Encinas JM, Fernández Vizarra P, Castro S, Peinado MA, Pedrosa JA, Richard A, MartínezMurillo, Santacana M, Bentura ML, Uttenthal RLO. El óxido nítrico: síntesis, neuroprotección y neurotoxicidad. Anales del sistema sanitário de Navarra. 2000;(23) Suppl. 2:195-236.
10. Orellana M, Rodrigo R, Thieleman L, Guajardo V. Bile duct ligation and oxidative stress in the rat: efects in liver and kidney. Comp Biochem Physiol C Toxicol Pharmacol. 2000;126:105-11.

11. Sokol RJ, Winklhofer-Roob BM, Devereaux MW, McKim Jr. JM. Generation of hydroperoxides in isolated rat hepatocytes and hepatic mitochondria exposed to hydrophobic bile acid. Gastroenterology. 1995;109:1249-56.

12. Yang S, Tan TM, Wee A, Leow CK. Mitochondrial respiratory function and antioxidant capacity in normal and cirrhotic livers following partial hepatectomy. Cell Mol Life Sci. 2004;61:220-9.

13. Oliveira e Silva A, Santo GC, Sesti FS, Rosa H. Colestase intra-hepática. In: Oliveira e Silva A \& Carneiro D'Albuquerque LA. Doenças do Fígado, Editora Revinter. 2001;291-319.

14. Mittal MK, Gupta TK, Lee FY, Sieber CC, Groszmann RJ. Nitrc oxide modulates hepatic vascular tone in normal rat liver. Am J Physiol. 1994;267:416-22.

15. Rockey DC, Chung JJ. Reduced nitric oxide production by endotelial cells in cirrhotic rat liver: endotelial dysfunction in portal hipertensión. Gastroenterol. 1998;14:344-51.

16. Pastor A, Collado PS, Almar M, González-Gallego J. Antioxidant enzyme status in biliary obstructed rats: effects of $\mathrm{N}$-acetylcysteine. J Hepatol. 1997;27:363-70.

17. Sokol RJ, Devereaux MW, Khandwala R. Effect of oxypurinol, a xanthine oxidase inhibitor, on hepatic injury in the bile duct-ligated rat. Pediatr Res. 1998;44:397-401.

18. Wang J, Gao GW, Gao RZ, Liu CA, Ding X, Yao ZX. Effects of tumor necrosis factor, endothelin and nitric oxide on hyperdynamic circulation of rats with acute and chronic portal hypertension. World J Gastroenterol. 2004;10:689-93.

19. Wein C, Hon WM, Lee KH, Khoo HE. Temporal expression of hepatic inducible nitric oxide synthase in liver cirrhosis. World J Gastroenterol. 2005;11:362-7.

\section{Acknowledges:}

Prof. Dr. Gustavo Ballejo, Sebastião Mazzetto

FAPESP - Fundação de Amparo À Pesquisa do Estado de São Paulo and FAEPA - Fundação de Apoio ao Ensino, Pesquisa e Assistência do HCFMRP-USP. 


\section{Correspondence:}

Paulo Roberto Barbosa Evora

Rua Rui Barbosa, 367, Apt.15

14015-120 Ribeirão Preto, SP - Brazil

Conflict of interest: none

Phone/Fax: (+55) 163602-2497

prbevora@netsite.com.br

\section{How to cite this article:}

Dias MA, Ceneviva R, Elias Jr. J. Zuccoloto S, Baldo CF, Evora PRB. Liver histological, portal flow and plasmatic nitric oxide alterations caused by biliary obstruction and drainage in rats. Acta Cir Bras [serial on the Internet], $2008 ; 23$ Suppl 1. Available from URL: http://www.scielo.br/acb.

\section{Comments:}

General presentation: the manuscript entitled " Histological liver portal flow and plasma nitric oxide alterations caused by biliary obstruction and drainage in rats" was adequately presented and in conformity to the technical Journal rules.

Introduction/objectives: recent and coherent literature reports on the subject are mentioned in the introduction. The objectives were to evaluate portal flux and plasma levels of nitric oxide induced by experimental biliary obstruction and posterior drainage. Methodology: the experimental model adopted by the authors is adequate and the biochemical and histological methods pertinent, besides employing Doppler measurements of the portal flow to meet the objectives proposed. Results: are presented sequentially, in a clear and didactic form, showing interesting aspects of the oxidative hepatic stress and of plasma levels of nitric oxide during the hepatic cholestasis. In addition, data about reversibility of pathological alterations following biliary obstruction relief are stressed by the authors. Discussion: results are argued and conclude that experimental biliary obstruction results in decreased portal flow, increased plasma nitric oxide levels and increased oxidative stress of the hepatic parenchyma, tending to normality after biliary drainage. Considering the above observations, the manuscript, "Histological liver portal flow and plasma nitric oxide level alterations caused by biliary obstruction and drainage in rats " should be published in Acta Cirurgica Brasileira.

\section{Fernando Silva Ramalho}

PhD, Department of Surgery and Anatomy, Ribeirão Preto Faculty of Medicine, University of São Paulo, Brazil. 